\title{
PENGARUH EARNING PER SHARE (EPS), RETURN ON ASSETS (ROA), NET PROFIT MARGIN (NPM) DAN DEBT EQUITY RATIO (DER) SECARA SIMULTAN TERHADAP TINGKAT KEUNTUNGAN SAHAM DI BURSA EFEK INDONESIA (BEI)
}

\author{
Hayu Yolanda Utami \\ Dosen Program Studi Pendidikan Ekonomi STKIP- PGRI Sumbar \\ Jl. Gunung Pangilun No.1, Padang Sumatera Barat \\ Email : Hayuyudha@gmail.com \\ submited: 2015.08.02 reviewed: 2016.06.16 accepted:2016.06.16 \\ http://dx.doi.org/10.22202/economica.2015.v4.i1.271
}

\begin{abstract}
This research analyzes whether the earnings per share (EPS), return on assets (ROA), net profit margin (NPM) and debt equity ratio (DER) with simultan affects the level of return of stock. Research methodology used in companies whose shares are actively traded on the basis of trading frequency in Indonesia known as LQ-45 firms, but only limited to non-financial companies in 2006 to 2008 in Indonesian stock exchange. The result of the research showed that the EPS, ROA, NPM, and DER have a significant impact either simultan conjunction with the level of return of stock and not the classical assumption deviation occurs after passing the autokorelasi, heterokedastisitas, multikolinearitas and normality tests
\end{abstract}

\begin{abstract}
Abstrak
Penelitian ini menganalisis apakah Earnings Per Share (EPS), Return On Assets (ROA), Net Profit Margin (NPM) dan Debt Equity Ratio (DER) secara simultan berpengaruh terhadap tingkat keuntungan saham. Metodologi penelitian yang digunakan dalam penelitian ini adalah perusahaan yang sahamnya aktif diperdagangkan berdasarkan frekuensi perdagangan di Indonesia dikenal sebagai LQ-45 companies tetapi hanya dibatasi pada perusahaan non keuangan tahun 2006-2008 di Bursa Efek Indonesia (BEI). Hasil penelitian menunjukkan bahwa EPS, ROA, NPM dan DER memiliki pengaruh yang signifikan secara simultan terhadap tingkat keuntungan saham dan tidak terjadi penyimpangan asumsi klasik setelah melewati uji autokorelasi, heterokedastisitas, multikolinearitas serta uji normalitas.
\end{abstract}

Keywords: Earnings Per Share (EPS), Return On Assets (ROA), Net Profit Margin (NPM), Debt Equity Ratio (DER) and Return of stock. 


\section{PENDAHULUAN}

Kinerja yang baik suatu perusahaan sangat diharapkan bagi manajemen perusahaan tersebut dan para investor karena selain dapat meningkatkan keuntungan perusahaan juga dapat meningkatkan pamor perusahaan dibandingkan perusahaan lain di masyarakat. Pada perusahaan yang go public (listed in $\mathrm{BEI}$ ) nilai perusahaan dapat dilihat dari harga sahamnya di Bursa Efek Indonesia (BEI) bila pasar modal dalam keadaan efisien. Nursiam dan Puteranto (2004) mengemukakan bahwa pasar yang efisien dapat menunjukkan harga saham yang mencerminkan secara penuh (fully reflect) informasi yang tersedia, informasi tersebut dapat berupa laporan tahunan perusahaan, pembagian dividen, pemecahan saham, laporan para analis pasar modal, dan sebagainya.

Pasar modal yang efisien menjadikan harga saham cenderung wajar dan stabil dan harga saham benar-benar mencerminkan nilai saham perusahaan yang bersangkutan hingga tidak ada harga saham yang melebihi harga wajar saham (overvalue) atau di bawah harga wajar (under value) sehingga investor semakin tertarik untuk berinvestasi pada saham tersebut karena harga saham yang wajar dan stabil membuat para investor lebih tenang dalam berinvestasi dan meningkatkan kepercayaan mereka untuk berinvestasi saham pada suatu perusahaan atau perusahaan yang telah dipercaya dalam jangka panjang. Nilai saham perusahaan merupakan nilai sebuah perusahaan, semakin tinggi nilai saham perusahaan serta stabil dan tidak berfluktuasi tajam dapat membuktikan kinerja perusahaan tersebut sangat baik dan layak dipilih sebagai investasi bagi investor.

Bila benar harga-harga saham di pasar modal Indonesia masih over value dan under value berarti pasar modal Indonesia belum efisien dan belum bisa dijadikan pilihan investasi utama yang aman bagi masyarakat. Menurut Husnan \& Pudjiastuti (2002), pasar modal efisien didefinisikan sebagai pasar yang harga sekuritas-sekuritasnya telah mencerminkan semua informasi yang relevan. Informasi merupakan unsur penting bagi investor dan pelaku bisnis karena informasi pada hakekatnya menyajikan keterangan, catatan atau gambaran baik untuk keadaan masa lalu, saat ini maupun keadaan masa yang akan datang bagi kelangsungan hidup suatu perusahaan dan bagaimana pasaran efeknya. Informasi yang lengkap, relevan, akurat dan tepat waktu sangat diperlukan oleh investor di pasar modal sebagai alat analisis untuk mengambil keputusan investasi. Sehingga para investor dapat memilih saham yang sesuai dan tidak merasa dirugikan. Pentingnya informasi yang jelas bagi investor sebelum memilih dan berinvestasi pada suatu saham perusahaan sangat membantu investor untuk lebih mengetahui kinerja perusahaan tersebut baik dimasa lalu dan saat ini.

Menurut Hartono (2003), informasi yang dipublikasikan sebagai suatu pengumuman akan memberikan signal bagi investor dalam pengambilan keputusan investasi. Jika pengumuman tersebut mengandung nilai positif, maka diharapkan pasar akan bereaksi pada waktu pengumuman tersebut dapat diterima oleh pasar dan pesatnya perkembangan BEI tempat mempublikasikan semua informasi tentang pasar modal saat ini tidak dapat dipisahkan dari peran investor yang melakukan transaksi di BEI. Para investor yang merupakan pihak yang akan berinvestasi dan memilih kepemilikan atas suatu perusahaan dengan membeli saham perusahaan tersebut, tentunya menginginkan keuntungan baik secara dividen maupun capital gain dan tentunya sangat meminimalisir terjadinya capital loss. Sebelum investor memutuskan akan mananamkan modalnya di pasar modal 
ada kegiatan yang perlu dilakukan, yaitu penilaian dengan cermat terhadap emiten (dengan membeli sekuritas yang diperdagangkan di bursa) memilih emiten yang layak untuk dijadikan investasi baik jangka pendek maupun jangka panajang. Salah satu faktor yang mendukung kepercayaan pemodal adalah persepsi atau pandangan mereka akan kewajaran harga saham dan keinginan untuk mendapatkan tingkat keuntungan saham yang lebih tinggi. Persepsi atau pandangan yang baik terhadap nilai suatu perusahaan tersebut akan tercipta dengan melihat track record perusahaan tersebut di masa lalu. Dalam keadaan seperti itu, pasar modal dikatakan efisien secara informasional.

Perkembangan BEI saat ini tidak dapat dipisahkan dari peran investor yang ingin melakukan transaksi BEI karena tanpa investor yang semakin banyak dan loyal maka BEI tidak dapat bekerja dengan lebih efektif, pada dasarnya investor berinvestasi dalam bentuk saham memiliki berbagai tujuan, seperti: memperoleh keuntungan dalam bentuk capital gain, memperoleh hak prioritas untuk memberi bukti right, memperoleh pembagian keuntungan dalam bentuk dividen serta mencari kemungkinan untuk memperoleh hak atas saham bonus dan sebelum investor memutuskan akan menginvestasikan dananya di pasar modal ada hal penting yang harus dilakukan investor tersebut yaitu melakukan penilaian dengan cermat terhadap emiten melalui informasi yang benar dari laporan keuangan yang dikeluarkan oleh emiten tersebut (Brigham dan Houston, 2006). Laporan keuangan suatu perusahaan mencerminkan tingkat kesehatan perusahaan tersebut dalam hal dana yang dimilikinya dan kemampuan perusahaan tersebut sehingga menjamin kelangsungan hidup perusahaan dimasa yang akan datang dan kemampuan suatu perusahaan dalam membayar kewajibankewajibannya. Laporan keuangan digunakan oleh para manajer untuk meningkatkan kinerja perusahaan, laporan keuangan digunakan oleh para kreditur untuk mengevaluasi kemungkinan pinjamannya dapat ditagih kembali dan laporan keuangan digunakan oleh para pemegang saham untuk meramalkan keuntungan dividen dan harga saham (Brigham dan Houston, 2006).

Oleh karena itu publikasi laporan keuangan merupakan saat-saat yang ditunggu oleh para investor karena dari laporan keuangan itulah para investor dapat mengetahui perkembangan kinerja keuangan emiten yang mencerminkan nilai suatu perusahaan dan tingkat kesehatan perusahaan tersebut sehingga adanya jaminan perusahaan tersebut tetap kuat dimasa yang akan datang sehingga dapat digunakan sebagai dasar sebelum memutuskan membeli atau menjual saham sebab apabila adanya kecendrungan meningkat merupakan garansi pengembalian (return) dari investasi investor dalam jangka panjang.

Laporan keuangan suatu perusahaan mencerminkan modal, kas dan kewajibankewajiban perusahaan yang dijelaskan melalui rasio-rasio keuangan suatu perusahaan. Menurut Brigham dan Houston (2006) berikut jenis-jenis rasio, seperti: Earning per Share (EPS) yang merupakan ukuran kemampuan perusahaan dalam menghasilkan keuntungan per-lembar saham bagi pemiliknya dan merupakan bagian dari rasio profitabilitas (Profitability Ratio), Return on Asset (ROA) yang merupakan rasio untuk mengukur kemampuan perusahan untuk memperoleh keuntungan (laba) secara keseluruhan dengan mempertimbangkan pengembalian atas total aktiva setelah bunga dan pajak, sehingga semakin besar ROA suatu perusahaan maka semakin besar juga tingkat keuntungan yang dapat dicapai perusahaan dan dapat mendorong nilai price earning ratio dan ROA ini merupakan bagian dari rasio 
profitabilitas (Profitability Ratio), Net Profit Margin (NPM) yang digunakan untuk mengukur seberapa besar laba bersih yang dapat diperoleh dari penjualan perusahaan dan bagi para investor, rasio ini dapat menjadi bahan pertimbangan dalam penilaian kondisi emiten karena semakin besar kemampuan emiten dalam menghasilkan laba maka secara teoritis harga saham perusahaan tersebut di pasar modal juga akan semakin meningkat, ini juga merupakan rasio profitabilitas (Profitability Ratio) dan selanjutnya Debt Equity Ratio (DER) yang menguraikan besarnya tingkat utang yang dimiliki oleh perusahaan. Dimana semakin besar utang suatu perusahaan maka semakin besar pula risiko perusahaan tersebut sehingga akan berdampak pada ketidakpastian harga saham, DER ini merupakan bagia dari rasio utang (Leverage Ratio). Berdasarkan uraian diatas dapat dilihat, yang dipilih sebagai variabel dalam penelitian ini adalah rasio profitabilitas dan rasio utang (Leverage) yang menggambarkan kemampuan perusahaan dalam menghasilkan profit (keuntungan) dan kemampuan perusahaan dalam membayar utangnya atau kewajibankewajibannya.

Studi sebelumnya yang dilakukan oleh

Rosyadi (2002) yang meneliti keterkaitan kinerja keuangan dengan harga saham yang menggunakan rasio keuangan profitability dan leverage. Penelitian ini menghasilkan temuan bahwa EPS, ROA dan NPM berpengaruh terhadap perubahan harga saham (PHS) baik secara parsial maupun bersama-sama (simultan) sedangkan untuk DER tidak berpengaruh terhadap perubahan harga saham, sehingga Rosyadi (2002) memberikan kesimpulan bahwa DER tidak dapat dijadikan pertimbangan bagi investor.

Oleh karena membandingkan dengan penelitian diatas dan penelitian lainnya, peneliti melakukan penelitian empiris dengan menggunakan rasio-rasio keuangan yaitu EPS, ROA, NPM dan DER tetapi menggunakan sampel perusahaan non keuangan dalam LQ-45 karena penelitian sebelumnya tersebut menggabungkan perusahaan keuangan dan non keuangan dalam analisis DER padahal itu terkesan tidak adil dan hasilnya tidak relevan dimana DER yang diperoleh positif yang berarti tingkat utang semakin tinggi sehingga semakin tinggi risiko yang akan ditanggung perusahaan padahal pada perusahaan keuangan (seperti: Bank) memiliki utang yang lebih tinggi dari modal, hal itu karena memang perbankan bertugas untuk menghimpun dana dari masyarakat (pihak ke 3) dalam bentuk tabungan, deposito, giro dan disalurkan lagi ke masyarakat (pihak ke 3) dalam bentuk pinjaman (kredit) sedangkan pada pasar non keuangan meminjam dana (utang) pada pihak lain apabila dirasa perusahaan tersebut kekurangan dana dan membutuhkan dana lebih untuk pengembangan dan invetasi yang secara otomatis risiko yang ditanggung perusahaan non keuangan lebih besar dibandingkan perusahaan keuangan dalam bentuk utang sehingga analisis DER pada kedua tipe perusahaan ini tidak dapat disamakan atau digabungkan karena memiliki sistem keuangan yang berbeda.

Berdasarkan latar belakang tersebut maka tujuan dari penelitian ini adalah untuk melihat bagaimana pengaruh Earning Per Share (EPS), Return On Asset (ROA), Net Profit Margin (NPM) dan Debt Equity Ratio (DER) secara bersama-sama (simultan) terhadap tingkat keuntungan saham perusahaan di Bursa Efek Indonesia (BEI).

\section{METODE PENELITIAN}

Populasi adalah wilayah generalisasi yang terdiri atas : obyek/subyek yang mempunyai kualitas dan karakteristik tertentu yang diterapkan oleh peneliti untuk dipelajari dan 
kemudian ditarik kesimpulannya (Sugiyono, 2013). Populasi dalam penelitian ini adalah perusahaan LQ 45 non keuangan yang terdaftar dan diperdagangkan pada Bursa Efek Indonesia (BEI). Sedangkan sampel adalah bagian dari jumlah dan karakteristik yang dimiliki oleh populasi tersebut (Sugiyono, 2013). Teknik sampling adalah Non Probability Sampling yaitu Purposive Sampling. Menurut Sugiyono (2013) sampling purposive adalah teknik penentuan sampel dengan pertimbangan tertentu. Yang menjadi sampel dalam penelitian ini adalah perusahaan LQ-45 Non keuangan yang terdiri dari 24 perusahaan yang telah lolos/ melewati kriteria yang telah ditetapkan sebelumnya untuk dapat dijadikan sampel.

Jenis penelitian yaitu kuantitatif, Menurut Sugiyono (2013) yang mana penelitian ini menggunakan perhitungan untuk menjawab rumusan masalah dan pengujian hipotesis yang diajukan.

\section{PEMBAHASAN}

\section{Hasil Pengujian Asumsi Klasik}

1. Uji Autokorelasi

Nilai tabel batas bawah (dl) Durbin Waston pada jumlah observasi 44 dengan jumlah variabel independen 4 pada temuan empiris ini adalah 1.285 dan batas atasnya (du) sebesar 1.721 , besaran ini akan menghasilkan nilai 4-du $=4$ $1.721=2.279$ dan $4-\mathrm{dl}=4-1.285=$ 2.715. Dalam batasan ini koefisien Durbin Watson (DW) sebesar 1.841 berada dalam daerah Non Autokorelasi.

Algifari (2000) untuk mengetahui terjadinya Autokorelasi, selain gambar maka digunakan tabel sebagai berikut:

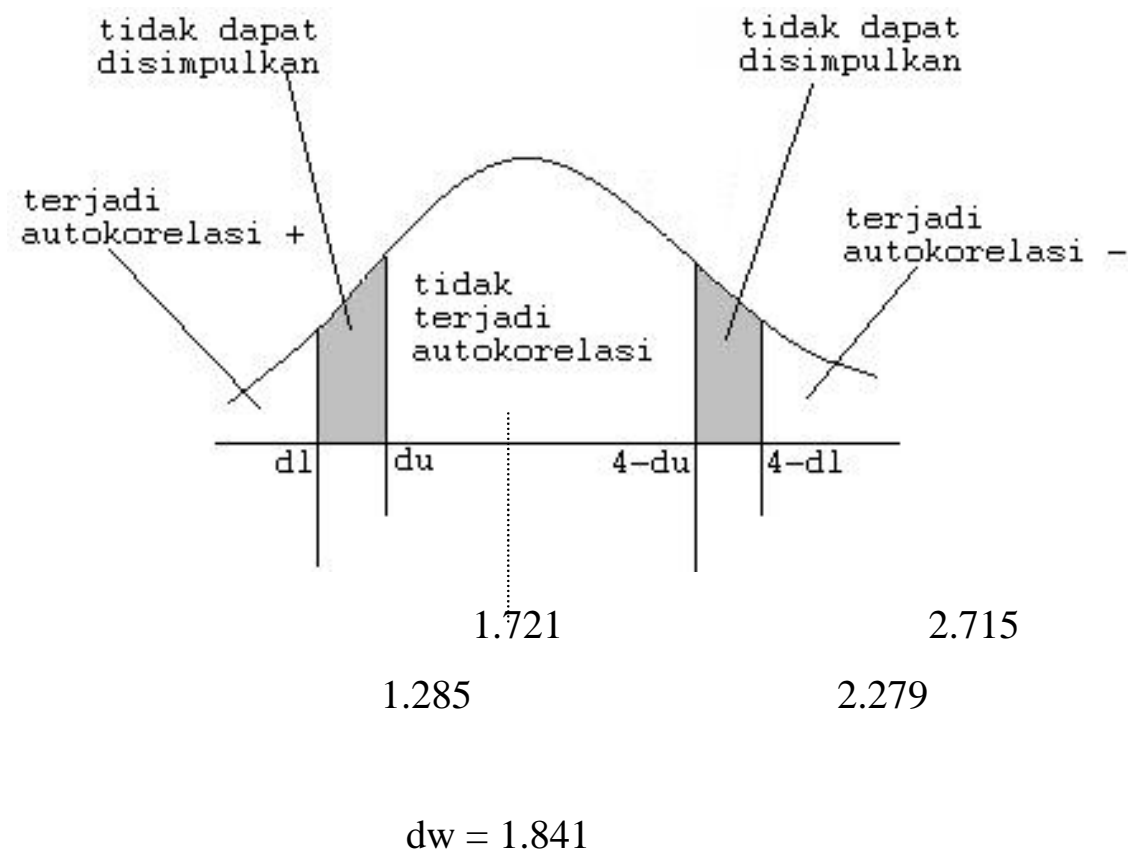

Gambar 1. Kurva Autokerelasi 
Berdasarkan perhitungan SPSS, nilai Durbin Watson (DW) sebesar 1,841 nilai DW terletak antara 1,55 sampai dengan 2,46 dengan kesimpulan tidak ada autokorelasi antar masing-masing variabel bebas dalam hal ini residu-residu yang saling berurutan tidak berkorelasi sehingga tidak terjadi pelanggaran Autokorelasi.

2. Uji Multikolinieritas

Pengujian ini untuk mengevaluasi independensi antar variabel independen untuk mengetahui adanya hubungan sempurna antar variabel dalam model regresi (Lind, Marchal dan Wathen, 2008). Bila memiliki Varian Inflation Factor (VIF) kurang dari 10 berarti independen atau tidak terjadi Multikolinieritas. Dari perhitungan program SPSS perolehan pengujian dalam tabel di bawah menunjukkan kurang dari 10 berarti tidak terjadi pelanggaran Multikolinier pada hasil regresi berganda ini.

Tabel 1. Hasil Pengujian Multikolinieritas

\begin{tabular}{lr}
\hline Faktor & VIF \\
\hline X1 - EPS & 2.182 \\
\hline X2 - ROA & 1.011 \\
\hline X3 - NPM & 2.156 \\
\hline X4- DER & 1.205 \\
\hline
\end{tabular}

Sumber: Hasil pengolahan data primer

\section{Uji Heteroskedastisitas}

Untuk mendeteksi terjadinya heteroskedastisitas dalam penelitian ini maka digunakan Metode Rank Spearman dengan cara meregresikan variabelvariabel bebas dengan variabel residual yang kemudian dikorelasikan secara matriks (Lind, Marchal dan Wathen, 2008). Apabila nilai probabilitas dari residual $>\alpha=0,05$ maka tidak terjadi gejala heteroskedastisitas begitu juga sebaliknya apabila nilai probabilitas dari residual $<\alpha=0,05$ maka akan terjadi gejala heteroskedastisitas.

Asumsi heterokedastisitas berkaitan dengan varian variabel pengganggu bila memiliki varian tidak konstan berarti terjadi heteroskedastisitas dan sebaliknya berarti homosedastis. Dalam tabel 2. di bawah tidak ada variabel independen yang memiliki hubungan signifikan dengan variabel pengganggu berarti besarnya varian pengganggu tidak berkaitan dengan jumlah observasi atau konstan dan dinyatakan tidak terjadi pelanggaran heterokedasitas. Apabila nilai probabilitas dari residual pada pengujian ini $>$ dari $\alpha=0.05$ yang berarti tidak terjadi pelanggaran heterokedastisitas.

Tabel 2. Hasil pengujian heterokedasitas

\begin{tabular}{cccc}
\hline Variabel & Residual & Probabilitas & Keterangan \\
\hline X1 - EPS & 0.108 & 0.486 & Tidak terjadi \\
X2 - ROA & 0.163 & 0.290 & pelanggaran \\
X3 - NPM & 0.048 & 0.759 & heterokedasitas \\
X4 - DER & -0.010 & 0.950 &
\end{tabular}

Sumber: Hasil pengolahan data primer 
Menurut Singgih (2005) dalam pengambilan keputusan melalui grafik Scatterplot adalah sebagai berikut:

a. Jika ada pola tertentu yaitu membentuk pola yang teratur (menyempit, melebar dan bergelombang) maka terjadi heterokedastisitas.

b. Jika tidak ada pola yang jelas, titiknya menyebar di sumbu Y maka tidak terjadi pelanggaran heterokedastisitas.

\section{Scatterplot}

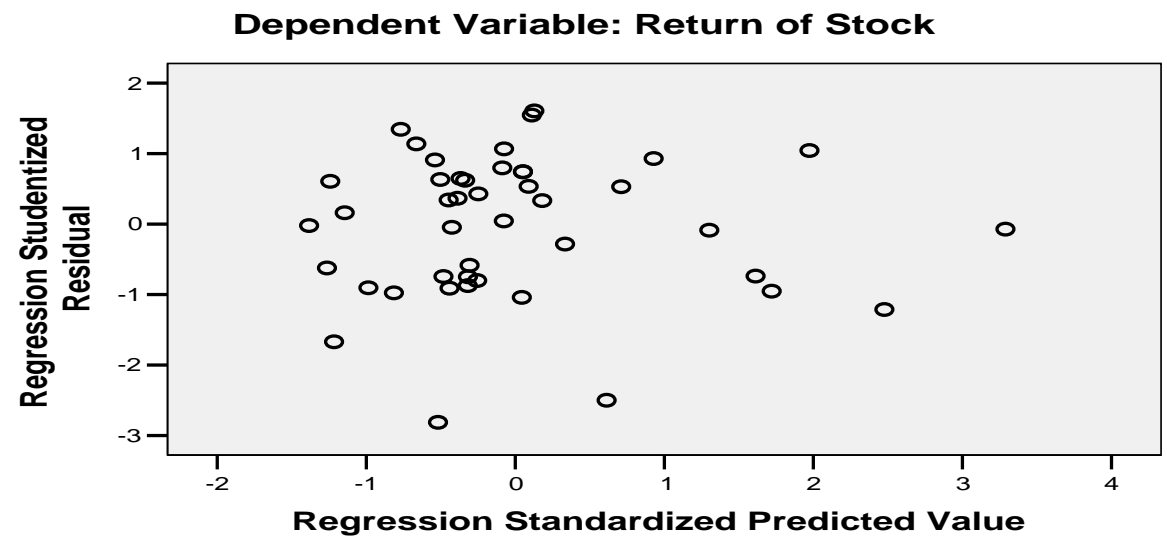

Gambar 2. Grafik Scatterplot

4. Uji Normalitas

Variabel pengganggu selain diasumsikan tidak memiliki hubungan serial dan memiliki varian konstan, juga diharapkan memiliki distribusi normal. Evaluasi kenormalan pada pengujian empiris ini dilakukan melalui grafik sebaran pengganggu dengan garis diagonalnya. Terlihat pada gambar 3. sebaran berada disekitar garis diagonal berarti normal. Hasil pengujian kolmogorov juga menghasilkan koefisien sebesar 0.740 dengan probabilitas sebesar 0.643, perolehan probabilitas > 0.05 menunjukkan distribusi normal.

\section{Hasil Pengolahan Data}

Berdasarkan olahan data berikut, dapat dijelaskan nilai $\mathrm{R}$ Square yang melihat seberapa besar pengaruh variabel EPS, ROA, NPM dan DER terhadap Tingkat Keuntungan Saham.

\section{Tabel. 3 Model Summary}

Model Summary ${ }^{b}$

\begin{tabular}{lccccr}
\hline \hline Model & $\mathrm{R}$ & R Square & $\begin{array}{c}\text { Adjusted R } \\
\text { Square }\end{array}$ & $\begin{array}{c}\text { Std. Error of } \\
\text { the Estimate }\end{array}$ & Durbin-Watson \\
\hline 1 & $.638^{\mathrm{a}}$ & .407 & .346 & .82262256 & 1.841 \\
\hline \hline & a. Predictors: (Constant), X4 Perubahan DER, X3 & Perubahan NPM, X2 \\
Perubahan ROA, X1 Perubahan EPS \\
b. Dependent Variable: Y Return of Stock
\end{tabular}


Berdasarkan tabel 3. diatas, dapat ditemukan besarnya pengaruh variabel seluruh variabel independen (secara simultan) yaitu variabel EPS, ROA, NPM dan DER terhadap tingkat keuntungan saham perusahaan non keuangan di Bursa Efek Indonesia (BEI) tahun 2006-2008 sebesar 0,407 atau sebesar 40,7\%. Dan sisanya sebesar $59,3 \%$ persen dipengaruhi oleh variabel-variabel lain yang dapat mempengaruhi kinerja keuangan perusahaan yang termasuk dalam rasio-rasio keuangan

perusahaan.

Tabel 4. Anova

\begin{tabular}{|c|c|c|c|c|c|c|}
\hline \multicolumn{7}{|c|}{ ANOVA } \\
\hline Model & & Sum of Squares & $d f$ & Mean Square & $\mathrm{F}$ & Sig. \\
\hline \multirow[t]{3}{*}{1} & Regression & 18.077 & 4 & 4.519 & 6.678 & $.000^{a}$ \\
\hline & Residual & 26.392 & 39 & .677 & & \\
\hline & Total & 44.468 & 43 & & & \\
\hline
\end{tabular}

Signifikansi pengaruh sebesar $40.7 \%$ ini dievaluasi melalui nilai $F_{\text {hitung }}$ bila besarnya sama atau melebihi $F_{\text {tabel }}\left(F_{\text {hitung }}\right.$ $\left.>\mathrm{F}_{\text {tabel}}\right)$ berarti signifikan, sebaliknya bila lebih kecil $\left(\mathrm{F}_{\text {hitung }}<\mathrm{F}_{\text {tabel }}\right)$ berarti tidak signifikan. Dalam gambar 4. terlihat $\left(\mathrm{F}_{\text {hitung }} 6.678>\mathrm{F}_{\text {tabel }} 2.612\right)$ dapat dilihat $F_{\text {hitung berada di daerah }}$ penerimaan Ha karena lebih besar dari $F_{\text {tabel }}$ sehingga EPS, ROA, NPM dan DER secara simultan berpengaruh terhadap tingkat keuntungan saham. Demikian juga bila dievaluasi berdasarkan probabilitasnya, perolehan probabilitas sebesar 0.000 lebih kecil dari 0.05 sehingga EPS, ROA, NPM dan DER secara simultan berpengaruh terhadap tingkat keuntungan saham.

Yang berarti EPS, ROA, NPM dan DER yang merupakan bagian dari rasio profitabilitas dan rasio utang suatu perusahaan secara bersama-sama (simultan) berpengaruh signifikan terhadap tingkat keuntungan saham. Semakin meningkat nilai EPS, ROA, NPM dan DER suatu perusahaan maka akan semakin meningkat tingkat keuntungan suatu perusahaan. Untuk EPS, ROA dan NPM berhubungan positif dengan tingkat keuntungan saham dimana semakin meningkat EPS, ROA dan DER maka akan semakin meningkat tingkat keuntungan saham. Tetapi DER berhubungan negatif dengan tingkat keuntungan saham, dimana semakin meningkat DER maka semakin menurun tingkat keuntungan saham perusahaan karena DER menujukkan besarnya utang yang dimiliki oleh suatu perusahaan.

Pada dasarnya semakin besar utang yang dimilki oleh suatu perusahaan sehingga semakin besar risiko yang akan ditanggung perusahaan tersebut karena perusahaan memiliki risiko yang lebih tinggi dibandingkan perusahaanperusahaan yang memiliki utang lebih kecil. Perusahaan yabg memiliki utang yang tinggi akan terbebani dan terpacu untuk mencari keuntungan yang lebih besar karena keutungan (profit) yang diperoleh harus dikurangi dengan membayar utang atau kewajibannya dan 
semakin berkurang modal untuk mengembangkan dan melakukan ekspansi perusahaan. Risiko lain perusahaan yang memiliki utang yang tinggi, apabila utang perusahaan tidak mampu dibayar, akan timbul risiko penyitaan agunan bahkan lama kelamaan perusahaan tidak mampu membayar utang akan mengakibatkan perusahaan tersebut menjadi bangkrut.
Hasil olahan data ini didukung oleh penelitian sebelumnya (Rosyadi, 2002) yang berdasarkan hasil perhitungannya diketahui bahwa nilai $F_{\text {hitung }}$ sebesar 17.370 dan $F_{\text {tabel }}$ sebesar 2.866 ini berarti bahwa $\left(\mathrm{F}_{\text {hitung }}>\mathrm{F}_{\text {tabel }}\right)$ sehingga $\mathrm{Ha}$ diterima yang berarti variabel EPS, ROA, NPM dan DER secara simultan berpengaruh terhadap perubahan harga saham.

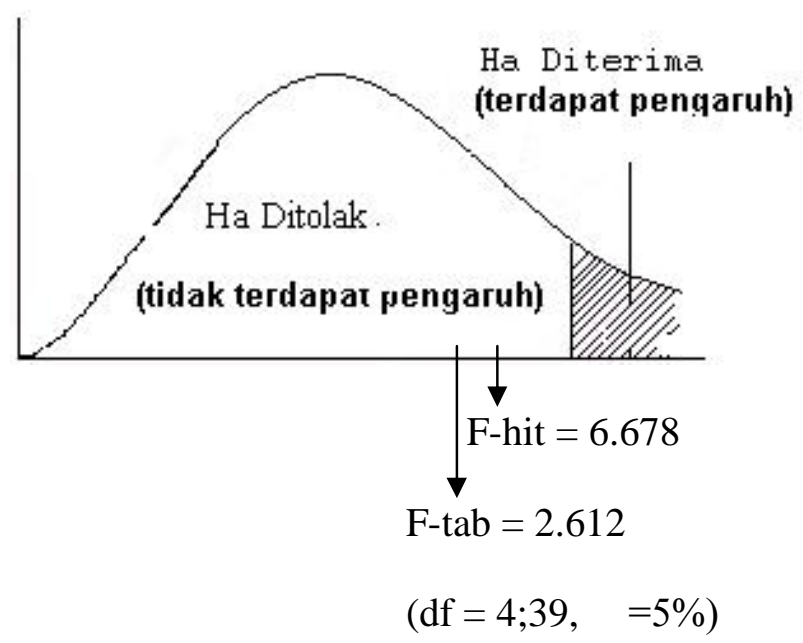

\section{Gambar 4. Signifikansi Pengaruh EPS, ROA, NPM dan DER secara Simultan}

\section{KESIMPULAN DAN SARAN}

Berdasarkan hasil olahan data dan penelitian, maka dapat ditarik kesimpulan sebagai berikut :

Variabel EPS, ROA, NPM dan DER secara simultan berpengaruh terhadap tingkat keuntungan saham. Dimana terlihat $\left(\mathrm{F}_{\text {hitung }}\right.$ $6.678>\mathrm{F}_{\text {tabel }}$ 2.612) dapat dilihat $\mathrm{F}_{\text {hitung }}$ berada di daerah penerimaan $\mathrm{Ha}$ karena $F_{\text {hitung }}>F_{\text {tabel }}$ sehingga EPS, ROA, NPM dan DER secara simultan berpengaruh terhadap tingkat keuntungan saham. Demikian juga bila dievaluasi berdasarkan probabilitasnya, perolehan probabilitas sebesar 0.000 lebih kecil dari 0.05 menghasilkan temuan bahwa EPS, ROA, NPM dan DER secara simultan berpengaruh terhadap tingkat keuntungan saham.

Untuk itu dapat disarankan bagi pembaca, investor dan peneliti selanjutnya, sebagai berikut :

1. Diharapkan para investor dan pembaca agar mempertimbangkan variabel lain selain EPS, ROA, NPM dan DER dalam memutuskan untuk memilih saham suatu perusahaan agar dapat memperoleh hasil yang baik seperti, mendapatkan perusahaan yang memiliki kinerja keuangan yang baik sehingga memiliki nilai perusahaan yang tinggi dan stabil dan para investor mendapatkan tingkat keuntungan saham yang diharapkan. 
2. Diharapkan pada peneliti selanjutnya, dikarenakan keterbatasan penelitian ini hanya pada perusahaan non keuangan dan hanya menggunakan 4 variabel independen maka peneliti selanjutnya dapat menambah variabel independen dan objek penelitian.

\section{DAFTAR PUSTAKA}

10.22202/economica.2015.v4.i1.271

Algifari. 2000. Analisis Regresi: Teori, Kasus dan Solusi. Edisi Kedua. Yogyakarta:BPFE.

Brigham, Eugene dan Joel F. Houston. 2006. Fundamentals of Financial Management. Teenth Edition. Thompson-South Western.

Hayu Yolanda Utami. 2012. Analisis Pengaruh Kinerja Keuangan terhadap Tingkat Keuntungan Saham (Return Of Stock). Economica Jurnal Program Studi Pendidikan Ekonomi STKIP PGRI Sumbar Vol.1 No.1 Oktober 2012, Hal. 83-94.

Hayu Yolanda Utami. 2013. Analisis Pengaruh Net Profit Margin (NPM) dan Debt Equity Ratio (DER) terhadap Return of Stock Perusahaan Non Ke3uangan dalam LQ-45 di Bursa Efek Indonesia (BEI). Economica Jurnal Program Studi Pendidikan Ekonomi STKIP PGRI Sumbar Vol.1 No.2 April 2013, Hal. 61-70.

Husnan, Suad dan Pudjiastuti, Enny. 2002. Dasar-dasar Manajemen Keuangan.
Edisi Ketiga. Yogyakarta: UPP AMP YKPN.

Hartono, Jogiyanto. 2003. Teori Portofolio dan Analisis Investasi. Edisi Ketiga. Yogyakarta: BPFE.

Indonesian Capital Market Directory (ICMD). 2008. Nineteenth Edition. Institute for Economic and Financial Research-ECFIN.

Lind, Douglas A, Wiliam G. Marchal dan Samuel A. Wathen. 2008. Statistical Techniques in Business and Economic with Global Data Sets. Thirdteen Edition. Mc Graw Hill.

Nursiam dan Lastiyono Puteranto. 2004. Analisis Efisiensi Pasar Modal Indonesia (Studi pada BEJ). Jurnal Akuntansi dan Keuangan. Vol.3 No.1, April 2004. Hal.1-23.

Rosyadi, Imron. 2002. Keterkaitan Kinerja Keuangan Perusahaan dengan Harga Saham (Studi pada 25 Emiten Menggunakan Rasio-Rasio Keuangan diP BEJ). Jurnal Akuntansi dan Keuangan. Vol 1 No.1, April 2002. Hal. 24-48.

Singgih, Santoso. 2005. Menguasai Statistik di Era Informasi dengan SPSS 13. Jakarta: PT. Elex Media Komputindo.

Sugiyono. 2013. Metode Penelitian Kuantitatif, Kualitatif dan $R$ \& D. Cetakan ke-18. Bandung: Alfabeta. 